\title{
System of Rice Intensification: A New Pathway of Rice Crop Establishment Method
}

\author{
Sunil Kumar* and Amrendra Kumar
}

Department of Agronomy, TCA, Dholi, Dr. Rajendra Prasad Central Agricultural University, Pusa, Samastipur(Bihar), India

*Corresponding author

\begin{tabular}{|c|c|}
\hline & A B S T R A C T \\
\hline $\begin{array}{l}\text { K e y w o r d s } \\
\text { System of rice } \\
\text { Intensification, Growth, } \\
\text { Yield and yield attributes, } \\
\text { Nutrient uptake, Seed } \\
\text { quality, Grain quality, } \\
\text { Water saving \& } \\
\text { Economics }\end{array}$ & \multirow{3}{*}{$\begin{array}{l}\text { System of rice intensification a new method is found to be an efficient } \\
\text { alternative to increase the rice production as it require less water, less seed, } \\
\text { reducing cost of cultivation and saving labour as compared to transplanted } \\
\text { rice. SRI appears to be a harbinger of post-modern agriculture, a new set of } \\
\text { technologies and practices that are based on biological evolution to the } \\
\text { problem raising agricultural productivity, superseding the engineering, } \\
\text { chemical and genetic solution of } 20^{\text {th }} \text { century. SRI is not only a set of } \\
\text { practices (Young seedlings, wider spacing, less water etc) but also a set of } \\
\text { insights and principles, with a philosophy which can reshape the paradigms } \\
\text { of agricultural products and its associated sciences. }\end{array}$} \\
\hline Articl & \\
\hline $\begin{array}{l}\text { Accepted: } \\
\text { 20 August } 2018 \\
\text { Available Online: } \\
\text { 10 September } 2018\end{array}$ & \\
\hline
\end{tabular}

\section{Introduction}

Rice is one of the most important cereals that hold the key for food security. It is the staple food for more than 70 per cent of people living in Asia where more than 90 per cent of it is produced and consumed. Method of rice culture has a significant bearing on the growth and development of rice plant, which ultimately governs its productivity. The system of rice cultivation in a region depends on specific ecological situation, type of soil, water sources, availability of labour, intensity and duration of rainfall (Singh, 1989). Direct seeding, broadcasting sprouted seeds on puddled soil and transplanting are the major planting methods of rice in India. Among the different methods of crop establishment, transplanting is the most dominant and traditional method in irrigated lowland rice (Biswas et al., 1991). Now-a-days, apart from this traditional method of transplanting innovative System of Rice Intensification (SRI) is becoming popular. System of Rice Intensification is a new methodology for rice production system.

The system of rice intensification was developed in Madagascar during the year 1980 after two decades of observation and 
experimentation (Laulanie, 1993). Application of SRI principles has helped small farmers in that country to greatly enhance their grain yields, from $2 \mathrm{t} \mathrm{ha}^{-1}$ to $8 \mathrm{t}$ $\mathrm{ha}^{-1} \quad$ (Hirsch 2000; Uphoff and Randriamiharisoa, 2002) on soils that were evaluated as poor or very poor (Johnson 1994). SRI method is focus on improving the growing environment of rice plants, above and below ground, by improving the management of plants, soil, water and nutrients, to stimulate the growth of bigger and better root systems and the number and activity of beneficial soil organisms (Hidayati et al., 2016). SRI involves the use of certain management practices which together provide a better growing condition for rice plants particularly in the root zone, than those for plants grown under traditional practices. There are three basic concepts constituting the System of Rice Intensification (SRI). They are to be applied with adjustments in specific practices like (i) Transplanting very young seedling $(<15$ days) i.e. prior to the start of fourth phyllochron of growth which preserves plant's potential for tillering and root growth that is reduced by later transplanting. Careful transplanting promotes rapid resumption of growth. (ii) Wider spacing with one seedling per hill paves way for profuse root and tiller growth achieving the border effect in the entire field. (iii) Keeping the soil moist and aerated during vegetative growth period makes the root access to both oxygen and water. Under continuous hypoxic conditions, rice roots degenerate with as many as $75 \%$ dysfunctional roots by panicle initiation (Kar et al., 1974). The potential within the plant is drawn out by giving them the best possible conditions for growth.

SRI methodology is gaining momentum all over the world, but, in India, it is in budding stage. There is ample scope to increase productivity of rice by altering the environmental conditions which ultimately modify micro-climate and soil condition as the phenotypic expression of any plant varies with $G \quad x \quad E$ (Genetic $x$ Environment) interaction. The System of Rice Intensification revolves around this concept. Research in several countries of the world confirmed that the shifting of rice husbandry from submergence to field capacity or nonflooding irrigations provide the most congenial growth promoting factors leading to increased productivity (Randriamiharisoa and Uphoff, 2002; Mustapha, 2002). Due to nonflooded irrigation during vegetative period it could be possible to reduce greenhouse gases (methane, etc) if this system proves to be promising on a large scale.

\section{Effect of SRI on growth and growth attributes}

Shrirame et al., (2000) reported that number of functional leaves, maximum leaf area and total number of tillers hill ${ }^{-1}$ were highest at wider spacing, but plant height, grain and straw yields and harvest index were not affected. Uphoff (2001) observed that with SRI methods, increased production was accomplished not by adding nutrients to the soil through fertilizers but by transplanting rice seedlings when they were very young (to maintain tillering and rooting potential) and then by growing them on well-drained soil. Gani et al., (2002) reported that seedlings (7 or 14 days old) performed better than 21 days old seedlings. The plants of young seedlings were taller and they produced longer and heavier roots, more number of effective tillers and biomass. Sebastien Rafaralahy (2002) observed that "Katayama-de-Laulanie tillering model" showed that three phyllochrons (growth periods) after the main tiller emerges i.e. during the fourth phyllochron, a first primary tiller tissue from the base of the main tiller, and then a second primary tiller emerges in the fifth phyllochron, etc. Seedlings should be 
transplanted before fourth phyllochron begins to preserve their tillering potential. He also reported examples of grain yields above $15 \mathrm{t}$ ha $^{-1}$ (ranging from 15.23 to $23.43 \mathrm{t} \mathrm{ha}^{-1}$ ) using SRI practices in Madagascar. Narayana Reddy (2002) reported that by $80^{\text {th }}$ day of sowing, on an average, 94 tillers per hill $(30 \mathrm{x}$ $30 \mathrm{~cm}$ spacing) were formed and by 90 days, 65 per cent of panicles had emerged. Tao longxing et al., (2002) reported that root growth was markedly greater in SRI plants than in traditional rice plants. Root dry matter and root depth was also more in SRI compared to traditional rice. They also reported that total dry matter production with SRI was higher than traditional rice, this difference became becoming significant during the reproductive stage. They reported less flag leaf photosynthesis rate with SRI than with traditional rice. Thiyagarajan et al., (2002) observed that at the active tillering stage (21 DAT) limited irrigation resulted in significantly higher tiller density than conventional irrigation $(5 \mathrm{~cm}$ depth 1 day after the disappearance of ponded water). Limited irrigation $(2 \mathrm{~cm}$ depth after surface crack development) resulted in higher tiller density throughout the rest of the growth period. They also reported that root volume increased from planting to the flowering stage and decreased at the grain filling stage. At the active tillering stage the root volumes of conventional and young seedlings were almost comparable. The increase in root volume from active tillering to panicle initiation was 110 per cent with young seedlings and 73 per cent with conventional seedlings. Qingquan (2002) reported that rice hybrid was found to have the highest yield potential when grown in SRI method, due to profuse tillering capacity, lodging resistance, greater stress resistance, enormous yield potential and wide ecological adaptability. The SRI practice facilitated larger individual plants and resulted in better light distribution, taller plants, higher base internodes weight bearing ability, larger total area and higher plant dry weight than conventional method. The yellow sheath in the base of the stem appeared later with SRI. This indicated that leaf senescence was delayed under SRI (Long Xing and Shaokai, 2002). Barison (2002) reported the appearance of more nodal roots for every newly formed tiller as well as a more developed root system which was the joint effect of better soil aeration provided by different water management practices and by transplanting of young seedlings. Shao-hua et al., (2002) reported enhanced root activity during the entire growth period, especially during later growth stages, higher contents of soluble sugar, non-protein nitrogen and proline in leaves, higher translocation and conversion rates of stored matter from vegetative organ in plants under SRI. This ultimately enhanced grain filling and spike weight in SRI. Sarath and Thilak (2004) reported that dry weights of stem, leaves, roots and the total plant weight per hill was greater throughout the growing season in the SRI treatment resulting in nearly 20 time higher total dry weight compared to conventional broadcasting and high density broadcasting and four times higher dry weight compared to conventional transplanting at the maturity. Average tiller number per plant was 29, 4, 2 and 1.5 in the SRI, conventional transplanting (three plants/hill with $15 \mathrm{~cm} \mathrm{x}$ $15 \mathrm{~cm}$ spacing), conventional broadcasting $(100 \mathrm{~kg}$ seeds/ha) and high density broadcasting). Per hill leaf area was significantly higher in SRI $\left(0.48 \mathrm{~m}^{2}\right)$ at heading stage compared to conventional transplanting $\left(0.01 \quad \mathrm{~m}^{2}\right), \quad$ conventional broadcasting $\left(0.03 \mathrm{~m}^{2}\right)$ and high density broadcasting $\left(0.02 \mathrm{~m}^{2}\right)$. The increased leaf area may be due to production of higher number of tillers/plant and leaves/tiller in SRI treatment. Mahajan (2006) opined that in SRI method significant phenotypic changes occur in plant structure and function but no significant yield differences were observed 
compared with the conventional transplanting technique. The SRI farming system may be attributed to the vigourous and healthy growth, development of more productive tillers and leaves ensuring greater resource utilization in SRI compared to conventional transplanting system. Saha and Bharti (2006) reported that amongst different crop establishment methods SRI (System of Rice Intensification) showed maximum plant height $(82.5 \mathrm{~cm})$, dry matter production $(558$ $\left.\mathrm{g} / \mathrm{m}^{2}\right)$ and number of tillers $\left(312.37 \mathrm{~m}^{-2}\right)$ as compared to drum seeder, line sowing and broadcasting methods, respectively. Highest number of tillers hill ${ }^{-1}$ was recorded in SRI with tillering continuing up to 50 DAT under SRI (Patel et al., 2006). Rao et al., (2006) found that SRI cultivation under $25 \times 25 \mathrm{~cm}$ spacing was superior for various physiological parameters such as root growth and LAI. The SRI method outperformed the normal planting in terms of growth attributes, root growth and yield (Zamir Ahmed et al., 2006). Wider spacing of $25 \times 25 \mathrm{~cm}$ gave border effect to all the plants in the field leading to robust growth, larger root and high tillering with big panicles (Satyanarayana, 2006). In SRI method the leaf area index (LAI) was higher i.e., 1.82 at tillering, 3.65 at panicle initiation, and 4.44 at flowering over the standard method with 4.40, 4.78, and 4.16 in the respective stages (Lokanadhan et al., 2007). Satyanarayana et al., (2007) confirmed that the SRI plants have deeper root systems and larger roots compared to those conventionally grown in flooded rice systems. In SRI method, the days to 50 per cent flowering and maturity stage arrived 4-5 day ahead of traditional method and it produced higher seed yield. Also productive tillers per plant and filled spikelets per panicle were higher in SRI method. (Krishna et al., 2008). In addition, single seedling is planted per hill with a wide spacing in SRI method. It reduces the competition between the plants for nutrients uptake, water, light and air which can significantly increase the growth of individual rice plant under the SRI method (Thakur et al., 2010). Sridevi and Chellamuthu (2015) reported that transplanting of 14 days old seedlings at a spacing of $22.5 \mathrm{~cm} \mathrm{x} 22.5 \mathrm{~cm}$ and cono weeding four times at weekly interval had profound contribution for the enhancement of growth parameters like leaf area index, crop growth rate, net assimilation rates, relative growth rate, leaf area ratio and dry matter. (Hidayati et al., 2016 observed that favorable conditions for growth with SRI methods allowed to complete more phyllochrons of growth, producing more tillers and roots, before the flowering phase

\section{Effect of SRI on yield and yield attributes}

The key reason for increased Harvest Index (HI) under SRI was producing fewer barren tillers and higher number of grains per fertile tiller (Khush, 1993). Abu Yameb (2002) reported that yield components like number of panicles $\mathrm{m}^{-2}$ and grains per panicle were more with SRI (448 and 122 respectively) over farmer's technique (338 and 95, respectively). Cessay et al., (2002) reported that in SRI, the panicle initiation and maximum tillering coincided with each other, while in conventional rice cultivation maximum tillering reached before PI (panicle initiation). According to SRI concept, the reduction in achievable yield with conventional rice cultivation was mainly due to the degeneration of the root system (Kar et al., 1974). SRI based on the synergetic development of both the tillers and roots. Vigourous root growth facilitated better access to the nutrients and water to produce more tillers and yield (Defeng et al., 2002). Mustapha Cessay and Norman Uphoff (2003) reported that under SRI, 1000-grain weight and biomass accumulation were higher by 6.7 and 20.1 per cent, respectively compared to conventional practice of continuous flooding. 
The average panicle setting rate $(32 \%)$ was only about half that from SRI management (58\%). Kumar (2003) found significantly higher grain yield at $25 \times 25 \mathrm{~cm}$ spacing for both 14 and 21 days seedling with higher values of yield components like effective tillers hill ${ }^{-1}$, spikelets panicle ${ }^{-1}$, grain panicle $^{-1}$ and panicle weight. Sarath and Thilak (2004) observed that yield components like number of panicles per hill and number of spikelets per panicle were remarkably higher in SRI though the total panicle number per unit area was higher in conventional broadcasting and high density broadcasting. Satyanarayana et al., (2004) observed a yield increase of $922 \mathrm{~kg} \mathrm{ha}^{-1}$ with SRI as compared to non SRI at Maruteru, Andhra Pradesh during summer. This was attributed to increase in number of productive tillers (16.7 $\%)$, filled grains per panicle $(29 \%)$, spikelet fertility $(6.4 \%)$, and test weight $(1.7 \%)$ with SRI than conventional method. Kumar et al., (2004) studied the effect of practices recommended in the system of rice intensification on yield attributes, yield and water productivity of rice ( $O$. sativa) and found that yield attributes like panicle length, number of panicles per hill, total number of grains per panicle were significantly higher in the treatment involving 14 day-old seedlings at $25 \mathrm{x} 25 \mathrm{~cm}$ spacing + water saving irrigation + LCC- based $\mathrm{N}$ management than in other treatments during wet season. Islam et al., (2005) reported that larger spikelet were found in plants grown in SRI plots compared with those grown in traditionally transplanted or direct sown plots. Rao et al., (2006) reported that yield attributing character such as tiller number, panicles per $\mathrm{m}^{2}$, spikelet number per panicle were superior under SRI cultivation at $25 \times 25 \mathrm{~cm}$ than under TRC (Traditional method of rice cultivation at $20 \times 10 \mathrm{~cm}$ (recommended for TRC). Ponni et al., (2010) reported that Higher yield attributes like number of productive tillers $\mathrm{m}-2$, length of panicle and numbers of grains panicle-1 showed the higher grain yield of $6082 \mathrm{~kg} / \mathrm{ha}$ which was significantly higher than conventional method of rice cultivation $(5223 \mathrm{~kg} / \mathrm{ha})$ under SRI system. Omwenga et al., (2014) observed that number of tillers, panicles, panicle length and panicle filling during the growth period of the crop to determine the effect of system of rice intensification and he revealed that drying period gave the highest yield of 7.13 tons/ha compared with the conventional method of growing rice which gave a yield of 4.87 tons/ha. There was an increase of $46.4 \%$ above the conventional method of growing rice.

\section{Effect of SRI on nutrient uptake}

Vallois and Uphoff (2000) reported that N, P and $\mathrm{K}$ uptake was more with SRI than conventional practices. Barison (2002) observed variation in nutrient uptake between SRI management and conventional practices with same variety. Crop with SRI management removed $91 \%$ more $\mathrm{N}$ and $\mathrm{K}$ and 66 per cent more $\mathrm{P}$ over conventionally grown rice. Uphoff and Randriamibarisoa (2002) observed that mycorrhizal fungi that "infect" roots helped maintaining a balance in the supply of nutrients to the plants as well as provided valuable protective services. They increased the accessed soil volume by as much as 100 times compared with noninfected root. Plants with mycorrhizal fungi could grow well with just a fraction of the $\mathrm{P}$ required for unassisted plants. However, since fungi cannot survive under hypoxic conditions, continuously irrigated rice had forgone the benefit of their association for centuries, even millenia. They also observed that under SRI, increase in both vegetative and reproductive biomass was apparently attributable to more efficient acquisition of soil nutrients ( $, \mathrm{P}, \mathrm{K}, \mathrm{Mg}, \mathrm{Cu}, \mathrm{Zn}, \mathrm{Ca}$ and Mo) and uptake of nutrients. Vallois and Uphoff (2000) reported that N, P and K 
uptake was more with SRI than with conventional practices. Barison (2002) observed variation in nutrient uptake between SRI management and conventional practices with same variety

\section{Effect of SRI on, seed quality and grain quality}

Udaykumar (2005) reported that better seed quality parameters under SRI method like higher germination per cent (95.56), root length $(5.44 \mathrm{~cm})$ and shoot length $(5.49 \mathrm{~cm})$ higher values of speed germination (31.11) and vigour index (991) compared to that under normal method. The vigour index was significantly higher with SRI. The better seed quality produced under SRI may be due to higher test weight values (Singh et al., 2013). Seed quality parameters viz., seedling length (root length and shoot length, separately), seedling dry weight and vigour index recorded significantly higher values in SRI method (Kumar, 2014). SRI was found better over traditional method in respect of grain quality of rice. Hulling, milling and head rice recovery in rice improved significantly under SRI over conventional method and this might be attributed to the improvement of root activity, dry matter accumulation and grain filling (Mandal et al., 2014). Milling percentage and head rice recovery were significantly higher $(4.4 \%$ and $4.8 \%$ during wet and dry season respectively) under SRI as compared to non-SRI (Satyanarayana et al., 2004) due to higher grain weight. Grain quality parameters such as the grain length (7.77 $\mathrm{mm})$, amylose content $(25.83 \%)$, alkali spreading value, Fe (2.06 ppm) and $\mathrm{Zn}$ (13.23 ppm) content (polished rice) recorded significantly higher values in SRI method compared to grain length $(7.47 \mathrm{~mm})$, amylose content $(25.09 \%)$, alkali spreading value, $\mathrm{Fe}$ (1.77 ppm) and $\mathrm{Zn} \mathrm{(12.07} \mathrm{ppm)} \mathrm{content}$ (polished rice) under conventional transplanting (CT) (Kumar, 2014). Kanaka
Durga et al., (2015) reported that the twelve days old seedlings planted at $25 \times 25 \mathrm{~cm}$ recorded $100 \%$ germination, with longer seedlings and seedling high vigour index I. Seed produced with SRI under spacing of 25 $\mathrm{cm} \times 25 \mathrm{~cm}$ recorded higher germination (98.60\%) as compared to conventional (95.0 $\%$ ) with close spacing of $20 \times 15 \mathrm{~cm}$.

\section{Effect of SRI on water saving in rice cultivation}

The most important feature of SRI technique its potentiality to save water. SRI is reported to reduce amount of water applied to the field by about $40-70 \%$ compared to the traditional practice of continuous flooding (Sato and Uphoff, 2007; Sinha and Talati, 2007). Zhao et al., (2010) reported that the total water consumption in SRI was $898.3 \mathrm{~mm}$ as compared to traditional flooding (TF) in which it was $1359.8 \mathrm{~mm}$. Water use efficiency (WUE) in terms of grain yield per unit consumed by water increased $91.3 \%$ for SRI. Irrigation water use efficiency (IWUE) in terms of grain yield per unit irrigation water improved by $194.9 \%$ for SRI compared to TF. SRI method of transplanting resulted in significantly higher total water productivity $(5.9 \mathrm{~kg} / \mathrm{ha}-\mathrm{mm})$ in upland ecology and (6.2 $\mathrm{kg} / \mathrm{ha}-\mathrm{mm}$ ) in lowland ecology as compared to other two methods viz. direct-seeded rice and puddled transplanted rice (Raj et al., 2017).

\section{Effect of SRI on economics}

Bruno Andrianarivo (2002) obtained a positive impact on farmers' income from diversified cropping with SRI through development of rotational cropping system. SRI farmers were have reported that their cost of production was usually half of conventional system and yield was high (Shao- Hua et al., 2002). SRI methods found to reduce risk. The cost of production under 
SRI was half the cost of conventional cultivation (Singh et al., 2006). Chellamuthu and Sridevi (2006) reported that combination of young seedlings, single seedlings, square planting and conoweeding registered the highest net return (Rs. 12,574/ha) and B: C ratio (1.87) compared to normal practice. The positive point for the spread of SRI for rice hybrid was that there was a saving of Rs. $1500 /$ ha in the seed cost besides that of water to an extent of 30 to 50 per cent (Viraktamath, 2006). Transplanting with 12 day old seedling at one seedling per hill under SRI recorded highest net profit (Rs. 40, 773 per hectare) and B: C ratio of 3.95 (Reddy et al., 2006). Ponni et al., (2010) compared the rice cultivation under system of rice intensification (SRI) and conventional method. The study revealed that the cost of cultivation was comparatively lesser in SRI than conventional method. The mean cost of cultivation for SRI and conventional method was Rs. 20,944 ha ${ }^{-1}$ and Rs. 23,111 ha-1, respectively. Thus it is evident that adoption of SRI was found to reduce the cost of cultivation by Rs.2167/ ha. SRI registered a total income of Rs.61,000 ha ${ }^{-1}$ and net profit of Rs.40, $056 \mathrm{ha}^{-1}$ as compared to Rs.52, 167 ha-1 and Rs. 29,056 ha $^{-1}$, respectively under conventional method. Higher BC ratio was also associated with SRI (2.91) than conventional method (2.26). The net returns and benefit-cost ratios were higher for SRI farms due to higher productivity of paddy cultivation (Durga and Kumar, 2013). Ram et al., (2014) concluded that use of 10 days old seedlings of hybrid rice 'PHB 71' at spacing of $25 \mathrm{~cm} \times 25 \mathrm{~cm}$ is most suitable to increase productivity and profitability of transplanted rice under Eastern Uttar Pradesh conditions. Nayak et al., (2016) evaluated economic advantages of SRI practices of paddy transplanting as compared to conventional method in Odisha. The yield differences showed that farmers growing paddy by SRI method could get a $6.6 \mathrm{q}$ more paddy as compared to traditional method of transplanting. Benefit: cost ratio indicated that SRI method was more effective as if we invest one rupee the total return would be 2.18 whereas in case of traditional method this figure would be 1.45 . Thus it can be concluded that with less inputs farmers can earn more. SRI could fetch 16.8 and 23.7\%higher gross return, 36.7 and $51.7 \%$ higher net return and 16.3 and $21.3 \%$ higher return re-1 invested than conventional transplanting and drum seeding, respectively as per mean yield. This was mainly because of higher yields obtained in SRI as compared to the other two methods during both the years (Mohanty, et al., 2014).

SRI could be a new technology of rice crop establishment that enhance the productivity of the crop with minimum use of resources. The practices of SRI like single seedling per hill and wider spacing helps the rice plants to higher utilize the water and nutrients thereby increase the water and nutrient use potency.

\section{References}

Abu Yameb (2002). The practice of the System of Rice intensification in Sierra leone. In: Assessments of the System of Rice Intensification (SRI). Proceedings of the International Conference, Sanya, China, April 1-4, 2002, pp. 103-105.

Barison, J. (2002). Evaluation of nutrient uptake and nutrient use efficiency of SRI and conventional rice cultivation methods in Madagascar. Research Report, Madagascar 3: 143-147.

Biswas, S., Shankaran and Palaniappan (1991). Direct seeding practices in India. In: Direct Seeded flooded rice in the Tropics. IRRI, Manila. Philippines. Pp. 55-63.

Bruno Andrianaivo (2002). Evaluation of the System of rice intensification in Fianaranisoa Province of Madagascar. 
p. 140-142. In: Research Report, Madagascar.

Ceesay, M, Uphoff, N., Fernandes, E., Long Pin Y., Sebastein, R. and Rabendrasana, J. (2002): Assessments of the Systems of Rice Intensification (SRI): Proceedings of an International Conference. Sanya, China April 1-4. Ithaca. New York (USA) CIIFAD, pp. 56-57.

Chellamuthu, V. and Sridevi, V. (2006). Relative contribution of different components of System of Rice Intensification (SRI) of yield of rice (Oryza sativa L.) Abstract: Second International Rice Congress p. 477-478.

Defeng, Cheng Shihua, Zhang Yuping, and Lin Xiaging (2002). Tillering pattern and the contribution of tillers to grain with hybrid rice and wide spacing. Research Report: China, 17: 125-131.

Durga, K.K., Rao, P.S. and Raju, K. 2015. Effect of seedling age and spacing schedule on the productivity and quality traits of rice under system of rice intensification (SRI). J. cereals oilseeds, 6:15-19.

Fernandes, E.C.M. and Uphoff, N. 2002. Summary from conference reports. In: Assessment of the System of Rice Intensification (SRI): Proceedings of an International Conference.

Gani, A., Rahman, A., Dahono, R. and Hengsdijk, H. (2002). Synopsis of water management experiments in Indonesia. In: Water wise Rice Production IRRI pp. 29-37.

Hidayati, N., Triadiati and Anas, I. 2016. Photosynthesis and transpiration rates of rice cultivated under the system of rice intensification and the effects on growth and yield. HAYATI J. Biosci., 23:6772.

Hirsch, R. 2000. La Riziculture Malgache Revisite'e: Diagnostic Perspectives (1993-99). Agence Franc, aise de
Development, Antananarivo, Annexes, pp. 13-14.

Islam, M.S.; Ahmed, G.J. U., Julfiquar, A.N. (2005). Effect of the System of Rice intensification on hybrid rice performance and yield. IRRN. 30 (2): 43-45.

Kar, S., S.B. Varade, Subramanyam, T.K. (1974). Nature and growth pattern of rice roots under submerged and unsaturated condition II. Riso, 23: 173179.

Khush, G.S. (1993). Breeding rice for sustainable agricultural system. In: D.R. Buxton et al., eds., International crop Science In: Proceedings of International crop science congress. Ames, IA, 14-22 July, 1992. Madison WI. Crop Science Society of America. pp. 189-199.

Krishna, A., Biradarpatil, N.K., Manjappa and Channappagoudar, B.B. (2008). Evaluation of system of rice intensification cultivation, seedling age and spacing on seed yield and quality in Samba Masuhri (BPT-5204) Rice. Karnataka J. Agric. Sci. 21 (1): 20-25.

Kumar, G. 2014. Evaluation of system of rice intensification (SRI) for enhanced seed yield and quality. M.Sc. (Ag.) Thesis. Acharya N G Ranga Agricultural University, Hyderabad, India.

Kumar, G. 2014. Evaluation of system of rice intensification (SRI) for enhanced seed yield and quality. M.Sc. (Ag.) Thesis. Acharya N G Ranga Agricultural University, Hyderabad, India.

Kumar, V.M. (2003). Evaluation of System of Rice Intensification (SRI) practices for higher production and productivity of rice. Ph.D. (Ag.) Thesis. Tamil Nadu Agricultural University, Coimbatore.

Kumar, V.M., Singh, S.D.S, Prabhakaran, N.K. and Thiyagarajan, T.M. (2004). Effect of SRI practices on yield attributes, yield and water productivity of rice (Oryza sativa L.) Acta- 
Agronomica-Han garica. 52(4): 399408.

Laulanie, H. 1993. Le systeme de rigiculture intensive malagache. Tropicultura (Brussels) 11: 104-114.

Long Xing, W. Xi and Shaokai (2002). Physiological effects of SRI methods on the Rice plant p. 132-136. In: Proc. International Conference Assessments of the System of Rice Intensification, Sanya, China 1-4 April, 2002.

Mahajan, G. (2006). The "System of Rice Intensification" (SRI); results from research trials in Punjab Agricultural University: further research requirements and prospects for adaptation to irrigated agro-ecosystems. In: National Symposium on SRI present status and future prospects, Nov. 17-18, 2006. Available online (www.wassan.org/SRI/abstracts.htm)

Mandal, M.K., Pramanick, M. and Bandopadhyay, P. 2014. Influence of crop establishment systems on yield and qualityof rice grain and seeds of aromatic rice (Oryza sativa L.). Green Farming, 5(6): 951-955.

Mohanty, T.R., Maity, S.K., Roul, P.K. and Sahoo, K.C. 2014.Studies on yield, economics and energetics of rice (Oryza sativa L.) in relation to crop establishment methods and nutrient management practices. Int. J. Bio-res. Int.J.Curr.Microbiol.App.Sci (2017) 6(11): 2315-2328 2325 Stress Manage, 5(4): 495-501.

Mustapha (2002). Revolution in rice intensification in Madagascar. Research Report, China 2: 89-94.

Mustapha Ceesay and Uphoff Norman (2003). The effects of repeated soil wetting and drying on lowland rice yield with system of Rice Intensification (SRI) methods. In http://ciifad.cornell.edu/. 110
Narayana Reddy, L. (2002). SRI method of paddy cultivation. LEISA, INDIA, Sept. pp. 28-29.

Nayak, C., Mahunta, R. and Dash, S. 2016. Economic Benefits of system of rice intensification (Sri) in Kendrapara district of Odisha. Int. J. Appl. Pure Sci. Agric., 2:220-225.

Omwenga, K.G., Mati, B.M., and Home, P.G. 2014. Determination of the Effect of the System of Rice Intensification (SRI) on Rice Yields and Water Saving in Mwea Irrigation Scheme. Kenya. J. Water Resource Prot., 6:895-901.

Ponni Priya, J. Veeraputhiran, R., Ganesaraja, V., Pandiselvi, T., and Pandian, B.J. 2010. Comparative study of system of rice intensification and conventional method of rice cultivation in Madurai district of Tamil Nadu. Int. J. Agric. Sci., 6(1): 186-188.

Qingquan, Y. (2002). The System of Rice Intensification and its use with hybrid rice varieties in China. p. 109-111. In: Proc. International conference. Assessments of the System of Rice Intensification. Sanya, China, April 1-4, 2002.

Raghuveer Rao, P., Mahender Kumar, R., Ram Prasad, A.S and Ravichandran, S. 2006. System of Rice Intensification (SRI) versus traditional method of rice cultivation (TRC). In: National Symposium on System of Rice Intensification (SRI) - Present Status and Future Prospects, November 17-18, 79.

Randriamibarisoa and Uphoff, N. (2002). Factorial trials evaluating the separate and combined effects of SRI practices. In: Assessments of the System of Rice Intensification (SRI). Proceeding of the International conference,

Rao, P.R., Kumar, R.M., Prasad, A.S.R. and Ravichandran (2006). System of Rice Intensification (SRI) versus Traditional 
method of Rice Cultivation (TRC). National Symposium on SRI present status and future prospects. Nov. 17-18, 2006. Available online (www.wassan. org/ SRI/abstracts.ht

Saha, A. and Bharti, V. (2006). Efficacy of different crop establishment methods on yield and economics of rice (Oryza sativa) in Sandy soil of Jammu region. In: National Symposium on SRI Present Status and future prospects, Nov. 17-18 (2006) available online. (www.wassan.org/SRI/abstracts.htm)

Sarath, P.N. and Thilak, B. (2004). Comparison of productivity of system of rice intensification rice farming system in Dry zone region of Sri Lanka. Cornell International Institute for Food, Agriculture and Development (on line) Internet $<$ http $>/ /$ ciffad.cornell.edu/sri.

Sato, S. and Uphoff, N. 2007. A review of onfarm evaluations of system of rice intensification (SRI) method in eastern Indonesia. In: Perspectives in Agriculture, Veterinary Science, Nutrition and Natural Resources. Commonwealth Agricultural Bureau International, Wallingford, UK.

Sato, S. and Uphoff, N. 2007. A review of onfarm evaluations of system of rice intensification (SRI) method in eastern Indonesia. In: Perspectives in Agriculture, Veterinary Science, Nutrition and Natural Resources. Commonwealth Agricultural Bureau International, Wallingford, UK.

Satyanarayana, P. V., Srinivas, T. and Satyanaraya, A. 2004. In Proc. World Rice Research Conference, Tsukuba International Congress center, Tsukuba, Japan. 4-7 Nov. 2004.

Sebastien Rafaralahy (2002). An NGO perspective on SRI and its origin in Madagascar. In: Assessments of the System of Rice Intensification (SRI): Proc. of the International conference,
Shao-hua, W., Weixing, C., Dong, J., Tingbo, D. and Yan, Z. 2002. Physiological characteristics and high yield

Singh, Chhidda (1989). Modern techniques of raising field crops. Oxford and IBH Publishing Co Pvt. Ltd. P. 20.

Sridevi, V.and Chellamuthu, V. 2015. Growth analysis and yield of rice as affected by different system of rice intensification (SRI) practices. Int. J. Res. App. Nat. Social Sci., 3:29-36.

Tao Longxing, Wang $\mathrm{Xi}$ and Min Shaokai (2002). Physiological effects of SRI methods on the rice plant. In: Assessments of the System of Rice Intensification (SRI): Proceedings of the International Conference. Sanya, China, April 1-4, 2002, ed.by N. Uphoff et at., pp. 132-136.

Thakur, A.K., Rath, S., Roychowdhury, S., Uphoff, N. 2010. Comparative performance of rice with system of rice intensification (SRI) and conventional management using different plant spacings. J. Agron. Crop Sci., 196:14659.

Thiyagarajan, T.M., Velu, V., Ramasamy, S., Durga Devi, D., Govindarajan, K. Priyadarshini, R., Sudha Lakshmi, C., Senthil Kumar, K. Nisha, P.T, Gayathry, G., Hengsdijk, H. and

Udayakumar, 2005. Studies on System of Rice Intensification (SRI) for seed yield and seed quality. M. Sc. (Agri) Thesis, Acharya N.G. Ranga Agricultural University, Hyderabad.

Uphoff, N. 2001.Opportunities for Raising Yields by Changing Management Practices: The System of Rice Intensification in Madagascar. Agro ecological innovations: increasing food production with participatory development. Earthiscan Publications Ltd., London, Sterilin, VA, pp. 145-161.

Uphoff, N. 2001.Opportunities for Raising Yields by Changing Management 
Practices: The System of Rice Intensification in Madagascar. Agro ecological innovations: increasing food production with participatory development. Earthiscan Publications Ltd., London, Sterilin, VA, pp. 145-161.

Uphoff, N. and Randriamiharisoa, R. (2002). Reducing Water use in irrigated rice production with the Madagascar System of Rice Intensification (SRI). In: Water wise Rice Production. IRRI, Philippines, pp. 71-87.

Vallois, P. and Uphoff, N. (2000). System of Rice Intensification (SRI) Malagasy Early Rice Planting system. Technical pages vol. 1.3, available online http:/ciifad.cornell.edu/SRI/.
Viraktamath, B.C. (2006). Evaluation of System of Rice Intensification (SRI) and conventional Rice culture (CRC) under varying nutrient management practices in aromatic rice (Oryza sativa). National Symposium on conservation Agriculture-October 2628, 2006, BHU, Varanasi. p. 276-277.

Zhao, M., Wu, L.H., Li, Y.S., Animesh, S., Zhu, D.F. and Uphoff, N. 2010. Comparisons of yield, water-use efficiency, and soil microbial biomass as affected by the system of rice intensification. Commun. Soil Sci. Plant Anal., 41:1-12.

\section{How to cite this article:}

Sunil Kumar and Amrendra Kumar. 2018. System of Rice Intensification: A New Pathway of Rice Crop Establishment Method. Int.J.Curr.Microbiol.App.Sci. 7(09): 3076-3086. doi: https://doi.org/10.20546/ijcmas.2018.709.384 